УДК 78.071 .1 (438) : 780.616.432.091] : 305

DOI 10.34064/khnum1-5612

\title{
Книш П. О.
}

ORCID 0000-0003-3791-7501

Харківський національний університет мистецтв імені І. П. Котляревського, 61003, майдан Конституиіï, 11/13, м. Харків, Україна

\section{Гендерний підхід в аналізі виконавських версій (на прикладі інтерпретацій Другого фортепіанного концерту Ф. Шопена Є. Кісіним, К. Аррау, Ланг Лангом, М. Аргеріх, Б. Давидович)}

АНОТАЦІЯ - Книш П. О. Гендерний підхід в аналізі виконавських версій (на прикладі інтерпретацій Другого фортепіанного концерту Ф. Шопена Є. Кісіним, К. Аррау, Ланг Лангом, М. Аргеріх, Б. Давидович). - Робота присвячена дослідженню гендерної своєрідності різних версій виконання Другого фортепіанного концерту Ф. Шопена з огляду на результати наукових праць, що звертаються до проблеми гендерної специфіки музичного виконання. Показана недостатня вивченість даного питання в галузі фортепіанного мистецтва. На матеріалі виконавських версій Є. Кісіна, К. Аррау, Ланг Ланга, М. Аргеріх та Б. Давидович зроблено спробу висвітити риси інтерпретації, обумовлені гендерним фактором, а також виконавські засоби, що застосовані видатними музикантами для розкриття художнього змісту шедевру епохи Романтизму. Отже, в чоловічих інтерпретаціях Концерту переважає інтелектуальна складова: увага до конструктивної побудови твору, прагнення до відтворення його більш ємного, філософського, змісту; в жіночих версіях переважає образно-емоційне начало, значна увага приділяється лірико-психологічним тонкощам, втілюваним відповідними засобами артикуляції, м'якістю туше. Перспективи подальшого дослідження передбачають аналіз гендерних особливостей виконавської творчості ряду сучасних музикантів. - Ключові слова: фортепіанний концерт, віртуозність, гендерний підхід, виконавський стиль, інтоначійно-тематичні особливості, інтерпретація, порівняльний аналіз. 
АННОТАЦИЯ - Кныш П. О. Гендерный подход в анализе исполнительских версий (на примере интерпретаций Второго фортепианного концерта Ф. Шопена Е. Кисиным, К. Аррау, Ланг Лангом, М. Аргерих, Б. Давидович). घ Работа посвящена исследованию гендерного своеобразия различных версий исполнения Второго фортепианного концерта Шопена с учётом результатов научных работ, обращавшихся к проблеме гендерной специфики музыкального исполнения. Показана недостаточная изученность данного вопроса в области фортепианного искусства. На материале исполнительских версий Е. Кисина, К. Аррау, Ланг Ланга, М. Аргерих и Б. Давидович предпринята попытка высветить черты интерпретации, обусловленные гендерным фактором, а также исполнительные средства, использованные выдающимися музыкантами для раскрытия художественного смысла шедевра эпохи Романтизма. Так, в мужских интерпретациях Концерта преобладает интеллектуальная составляющая: внимание к конструктивному построению произведения, стремление к воссозданию его более ёмкого, философского, содержания; в женских версиях превалирует образно-эмоциональное начало, значительное внимание уделяется лирико-психологическим тонкостям, воплощаемым соответствующими средствами артикуляции, мягкостью туше. Перспективы дальнейшего исследования предполагают анализ гендерных особенностей исполнительского творчества ряда современных музыкантов.

- Ключевые слова: фортепианный концерт, виртуозность, гендер, исполнительский стиль, интоначионно-тематические особенности, интерпретация, сравнительньй анализ.

ABSTRACT - Knysh P. O. Gender approach in the analysis of performing versions (on the example of F. Chopin's Second Piano Concerto performed by E. Kissin, C. Arrau, Lang Lang, M. Argerich, B. Davidovich).

Background. The work focuses on studying gender peculiarities of interpretations of the Second Piano Concerto by F. Chopin. Presenting the results of the scientific works that concern the issue of gender peculiarities of performing music, the author comes to the conclusion about lack of research of this question in the field of piano art. While the contemporary social and psychological works of the domain of gender turn to the primary signs of gender differences, embodied still at the point of the earliest stage of personality formation, starting with the very birth of a child (Bendas, T., 2006 et alt.). For instance, still in their childhood girls 
develop such features as a higher intensity emotionality, subtleness of feelings, whereas boys tend to be more rational while thinking over life situations or works of art. Such psychological peculiarities are revealed for various life periods and get more distinct in the process of age advancement.

Research methodology. In this article the gender approach is combined with the comparative method while considering key features of different performance versions of the Second Piano Concerto by F. Chopin. Appealing to the performance versions of E. Kissin, C. Arrau, Lang Lang, M. Argerich, B. Davidovich, we emphasize their uniqueness with a simultaneous focus on performance tools used by these prominent musicians to reveal the essence of this masterpiece of the Romantic era. The purpose of this article is to generalize the tendencies of the performing concepts of Chopin's Second Concerto by the famous masters of piano art of the XX - early XXI century in the light of gender approach.

Research results. The Second piano concerto, created by F. Chopin at the turn of the 20 s- 30 s of the XIX century, has become a model of the innovative approach both to interpreting the genre in general and to piano virtuosity. Firstly, it is expressed through the dominance of the pianoforte over the orchestra, while the former being characterized by the total melodization of the texture. Researchers of F. Chopin's creativity point out the fact that in his concertos there are influence traces of W. Mozart, C. Weber, J. Hummel; however, despite the belonging of the concertos to early stage of creative activity, Chopin achieves unique artistic results. Maintaining, just like Mozart's, the classical structured transparent form, enriching musical textures with passages, just like Hummel, Chopin, nevertheless, presents deeply individual images. If in the First part of the Second Concerto the dependence on classical traditions is still obvious, the Second part and the Final demonstrate broad horizons for the lyric component of the composer's music.

Before we turn to a number of outstanding samples of the Second Concerto performance, we recall the opinion of one of the best pianist-interpreters, E. Fisher, that the sound embodiment of a musical work consists of three elements: musical text, instrument and artist (Fisher, E. 1977: 201). He noted that the musical text is an unshakable material basis for the performer. Interpretation is possible only under the condition of accurate transmission of what is stated in the author's text reflecting both the development of the playing technique and the improvement of musical instruments. At the same time, the end result - the sound image of the work - arises under the influence of the artist's personality, reflecting its qualities, 
such as "the degree of development of intelligence, worldview, especially emotional life, belonging to one or another artistic type" (ibid.). So, performers who turn to the Second Concert, can accent certain elements, lines, forming its rich semantic complex.

If we classify performing versions of the Chopin Concert by gender qualities, we can come to certain conclusions.

In the male versions studied we have clearly revealed the constructivism in musical arrangements, an intellectual structure, rational forethought concerning all the stages of musical development. A special emphasis is laid on caesuras and differentiation between various types of musical material, clearly bespeaks pianists' intention to reflect more comprehensively a philosophical content of the work. The peculiar predominant feature as for E. Kissin's performance is his lyric-psychological interpretation of the image palette of the Concerto. Kissin's main way of realizing the corresponding tasks is articulation that emphasizes the uniqueness of each episode. In the performance of C. Arrau we notice a characteristic brightness, emotionality, contrasting effect, thanks to the intensive exploitation of agogics; at the same time, the unity of the music form is reached through the exactness of the meter and rhythmic pulsation. Lang Lang's version is a model of a supreme sound lyricism. The pianist plays in the style of Mozart with a clear texture, rationed pedalizing and agogics. At the same time, in his performance there is a philosophical generalization that can be perceived.

In comparison with the male versions, the female ones, on the whole, are peculiar in terms of their subtler sound richness, touché softness. In the interpretation of the drama lines of the Concerto it is the image-emotional component that prevails but, together with this, a special emphasis is laid on lyric and psychological details. The analyzed interpretation by B. Davidovich is characterized by a specific style of its own as, while building up the performance dramaturgy of the Concerto, she prefers a through theme development, without dividing the sound stream into separate fragments the way many performers prefer to do. M. Argerich understands this music by F. Chopin in a different way. Her performance style is unique due to its high drama intensity, emotionality, passion, introducing elements of rationalism into the drama line of the Concerto. Key words: piano concerto, virtuosity, gender approach, performance style, intonation, thematic peculiarities, interpretation, comparative analysis. 
Постановка проблеми та аналіз публікацій за темою. Останнім часом гендерний підхід набуває все більшого значення у вивченні та аналізі музично-виконавських концепцій. Особливо це стосується вокального мистецтва. Так, серед робіт дослідників, котрі звертаються до проблеми гендеру у виконавській творчості, відзначимо працю В. Гіголаєвої-Юрченко (2012), яка розробила методику аналізу гендерних репрезентацій вокального твору. Однак не менш цікавим виявляється застосування можливостей гендерного підходу до фортепіанного виконавства, яке з даних позиції ще не поставало об'єктом спеціальних досліджень.

Гендер (запозичення з англійської, де слово «gender», що походить від лат. genus - «рід», первісно означало «граматичний рід», пізніше - також «стать») - якщо узагальнити визначення цього поняття в сучасних соціально-психологічних науках - характеристика, через яку визначається наявність особливостей чоловічого (маскулінного) або жіночого (фемінного) типів соціальної поведінки та світовідчуття (свого роду «соціально-психологічна проєкція» статевої приналежності людини, їі «соціальна / психична стать»). У сучасних дослідженнях гендерних питань (Бендас, Т., 2006; Гапова, Е., \& Усманова, А., 2000 та ін.) проблема ставиться максимально широко: гендерні розбіжності відстежуються, починаючи від перших психічних проявів статевих відмінностей, які спостерігаються вже на етапі найбільш раннього формування майбутньої особистості - від народження дитини та перших кроків у формуванні іiі здібностей. Так, у дівчаток уже 3 дитинства виявляються такі риси, як підвищена емоційність, тонкощі переживань, в той час, як хлопчики демонструють більшу схильність до раціоналізму в оцінюванні життєвих і творчих ситуацій, зокрема, й творів мистецтва, до аналізу яких, згідно думці В. Гіголаєвої-Юрченко (2012: 7), теж необхідно застосовувати гендерний підхід. За спостереженнями психологів (Бендас, Т., 2006), ці особливості по-різному проявляються у функціональному плані, але зберігаються і поглиблюються, окреслюючи різні аспекти еволюції людського світовідчуття і світосприйняття.

Комплексний гендерний підхід стосується всіх сторін діяльності людини, аналізуючи їі поведінку в різних життєвих і творчих сфе- 
рах. Зокрема, він може бути плідно застосований і в царині музичної творчості - композиторської та виконавської. Музичний твір ніколи не є абстракцією; він існує лише у реально-звуковому сприйнятті як продукт виконавської інтерпретації. Гендерна приналежність виконавця, впливаючи на його поведінку в умовах творчого акту, позначається й на його стилі, що відображається на техніці та прийомах, наприклад, тієї ж фортепіанної гри.

Мета даної статті полягає у виявленні особливостей виконавських концепцій Другого концерту Ф. Шопена в інтерпретації відомих майстрів фортепіанного мистецтва XX - початку XXI ст. (Є. Кісіна, К. Аррау, Ланг Ланга, М. Аргеріх, Б. Давидович) в світлі гендерного підходу.

Методологія дослідження. В роботі використовується гендерний підхід, що є базовим в її методології, у поєднанні з компаративним, який $є$ необхідним для порівняння різногендерних виконавських версій Другого фортепіанного концерту Ф. Шопена.

Виклад основного матеріалу дослідження. Другий концерт для фортепіано $з$ оркестром (ор. 21) Ф. Шопена створювався протягом 1829-1830 рр., а вперше був виданий, згідно з даними, наведеними в монографії польського дослідника М. Томашевського (2011), у 1836 р. Відтоді він виконувався безліч разів і заслужено завоював репутацію одного $з$ найбільш яскравих творів фортепіанної концертної літератури. Концерт став зразком принципово нового підходу як до трактовки самого жанру, так і до вирішення питань фортепіанної віртуозності (за Л. Мазелем, 1971). Це виражається, за М. Томашевським (2011), насамперед, в домінуванні фортепіано над оркестровою партією, що дещо знижує статус concertanto як втілення рівноправного змагання двох учасників. Тотальна мелодизація фактури, насиченість музичної тканини найрізноманітнішими пасажами та орнаментикою, наповненість глибоким поетичним змістом гармонійно поєднуються з віртуозним стилем brilliante, який він не лише відтворює, але й «перевершує» (там само).

Численні дослідники творчості Ф. Шопена відзначають в його концертах впливи В. А. Моцарта, К.-М. Вебера і, особливо, Й.-Н. Гуммеля - знаменитого тоді піаніста і автора популярних вір- 
туозних п’єс. Однак, незважаючи на появу концертів у ранній період творчості, Ф. Шопен приходить у них до самобутніх художніх результатів. Зберігаючи класичну, струнку, як і у В. А. Моцарта, форму, насичуючи, як і Й.-Н. Гуммель, фактуру пасажами, Ф. Шопен створює вражаючі образи різного психологічного змісту, переважно, ліричного $з$ елементами драматизму.

У першій частині Концерту найбільш відчутна залежність від класичних традицій. Друга частина та Фінал відкривають великий простір ліричному потоку музики композитора. Як відзначав сам Ф. Шопен у листі до свого друга Т. Войцеховського (Шопен, Ф., 1989: 328), в Другій частині концерту відобразилися його почуття до юної співачки Констанції Гладковської. Largetto залишає враження щирого почуття, котре вилилось 3 глибин душі. Це - одна 3 самих теплих, ліричних сторінок музики композитора. Тут немає драматизму, а тим паче, трагедійності, але мрійлива ніжність часто змінюється піднесеною схвильованістю. Речитативи в партії фортепіано нагадують виразність людської мови і звучать, як пристрасні слова кохання. В перших же тактах Largetto виявляється надзвичайна характерна риса шопенівської мелодики: кантилену, яка вільно ллється, Ф. Шопен переводить у вишукані звукові арабески, i, навпаки - примхливі пасажі органічно зливаються з плавною співучою мелодією. Як в першій частині Концерту, так і в Largetto, композитор спирається на польські народно-пісенні інтонації. Ще відчутнішими зв'язки 3 польським народним музичним мистецтвом стають у Фіналі, де панує танцювальна ритміка з рисами мазурки. Загальний тон музики Фіналу характеризується енергією стрімкого і пронизаного легкістю руху, чому сприяє багатозвучна i, в той же час, прозора фортепіанна фактура.

Як бачимо, образний зміст твору яскраво виявляє схильність до жіночності, підвищеної емоційності, витонченого ліризму. Тому цікаво розглянути не лише зміст і форму Концерту, але й виконавські його версії, представлені надзвичайно широко в сучасній музичній практиці, у тому числі і з точки зору виявлення в них обох гендерних начал - як чоловічого, так і жіночого. Жіночий гендер суттєво впливає на характер і втілення музичних образів Концерту, відтворюючи враження надзвичайної легкості, пов'язане не тільки з витонченістю 
мелодичного малюнку, прозорістю гармонії і фактури, а й зі стрімким тріольним рухом, котрий особливо характерний для Фіналу.

Перш, ніж ми звернемося до ряду видатних зразків виконання Другого концерту, нагадаємо, що один з найкращих інтерпретаторів Й. С. Баха, В. А. Моцарта, Л. Ван Бетховена, Р. Шумана, відомий швейцарський піаніст Е. Фішер, висловив думку про те, що звукове втілення музичного твору складається з трьох елементів: нотного тексту, інструменту і виконавця (Фишер, Э., 1977: 201). Він зауважував, що нотний текст - це непорушна матеріальна основа для виконавця. Інтерпретація можлива лише за умови точної передачі того, що викладено в авторському тексті, який відбиває і розвиток техніки гри, і вдосконалення музичних інструментів. Та кінцевий результат - звуковий образ твору - виникає під впливом індивідуальності виконавця, відображаючи іiї якості, такі як «ступінь розвитку інтелекту, світогляд, особливості емоційного життя, приналежність до того чи іншого художнього типу» (там само). Отже, виконавці, котрі звертаються до Другого концерту, можуть акцентувати певні елементи, лінії, що утворюють його багатий смисловий комплекс.

Якщо ж класифікувати за ознаками гендерних якостей виконавські версії шопенівського Концерту, можна дійти певних висновків.

У виконанні чоловіків, зокрема, Є. Кісіна, виявлені такі тенденції: 1) прагнення до звукового балансу контрастних розділів форми; 2) переважання лірико-психологічної трактовки образно-емоційного змісту; 3) спрямування до єдності темпів; 4) системність в агогічних відхиленнях; 5) особливий акцент на артикуляції, що стає ключем до реалізації як авторського задуму, так і виконавської інтерпретації.

- Щодо виконання К. Аррау, відзначимо такі риси: 1) прагнення до особливої виразності кожного елемента шопенівського тексту; 2) різкі контрасти темпу і агогіки на всіх рівнях форми; 3) акцент на концертно-віртуозній, афектній трактовці звукового матеріалу в передачі образно-емоційних станів; 4) велика кількість агогічних відхилень; 5) компенсаторна функція метро-ритмічної пульсації, яка надає єдності імпровізаційній виконавській структурі Концерту.

- Для версії Ланг Ланга характерними є: 1) увага до окремих деталей, на основі яких відтворюється картина музичної інтерпре- 
тації кожної частини; 2) по-моцартівському класичне окреслення кожного елементу фактури, чітка артикуляція мелодичних зворотів; 3) увага до загальної драматургії Концерту, підкреслення контрастів імпровізаційного і жанрово-танцювального начал (марш в першій частині, вальс - у Фіналі); 4) класично прояснені агогічні розширення в кульмінаціях кожного пасажу або кадансового гармонічного звороту; 5) спроба виявити філософський підтекст Концерту, де кожний контрастний епізод $є$ складовою макрокосму усього твору, елементом чогось більшого.

Усі ці три версії Концерту свідчать про увагу піаністів-чоловіків до загальної авторської концепції, процесів формоутворення, що вимагає системного підходу до комплексу засобів виконавської виразності - артикуляції, темпу, агогіки, метро-ритму, ритмічної і гармонічної пульсації.

У жіночих версіях виконання Концерту переважають інші інтерпретаційні акценти.

- У версії Б. Давидович типовими є такі, які підкреслюють зв'язок шопенівського і моцартівського піанізму у вигляді: 1) прозорості звукової тканини, чіткої артикуляції, чому сприяє економна педалізація; 2) збереження єдиного темпу і характеру руху при мінімумі агогічних відхилень; 3) прагнення до наскрізного розвитку форми, при якому звуковий потік майже не розчленовується на окремі фрагменти, що зумовлено нахилом до імпровізаційності, особливо, у Largetto та Фіналі.

- Відома виконавиця фортепіанної музики Ф. Шопена М. Аргеpix дещо по-іншому трактує музику Концерту, надаючи їй більшої емоційності, пристрасності, поєднуючи це з елементами раціоналізму у виконавській драматургії твору. В її виконанні відзначимо: 1) насичену темброву палітру, що досягається завдяки динамічним контрастам у викладі окремих тем та розділів форми; 2) темпові контрасти та агогічні відхилення, які сприяють виявленню характеру тем як на грані різних тематичних утворень, так і у внутрішньому тематичному контрастуванні; 3) м'яке туше, притаманне виконавській манері М. Аргеріх взагалі, що зближує іiі з вокальним інтонуванням; 4) особливу насиченість звуку, котра наближує іiї виконання до маскулінного типу. 
Висновки. Отже, в чоловічих версіях виконання Другого концерту Ф. Шопена переважає тяжіння до виявлення конструктивної основи твору, його інтелектуальної побудови, продуманості усіх етапів музичного розвитку. Велике значення піаністи-чоловіки надають цезурам, контрастам, розмежуванню різного за образністю музичного матеріалу, прагнучи до відтворення його більш ємного, філософського, змісту.

Жіночі версії порівняно з чоловічими в цілому відрізняються меншою звуковою насиченістю, м'якістю туше. У прочитанні драматургії Концерту переважає образно-емоційна складова, значна увага приділяється лірико-психологічним тонкощам, відтворюваним відповідними засобами артикуляції.

\section{ЛІТЕРАТУРА}

Бендас, Т. В. (2006). Гендерная психология: учеб. пособ. Санкт-Петербург: Питер, 431.

Гапова, Е., \& Усманова, А. (Сост.) (2000). Антология гендерной теории. Минск: Пропилеи, 384.

Гиголаева-Юрченко, В. (2012). Гендерно-исполнительский анализ романсов С. Рахманинова: «О нет, молю, не уходи» (И. Архипова) и «Полюбила я на печаль свою» (Б. Христов). Проблеми взаємодї мистецтва, педагогіки та теорії і практики освіти, 34, 293-301.

Корыхалова, Н. (1979). Интерпретация музыки. Ленинград: Музыка, 208.

Мазель, Л. А. (1971). Исследования о Шопене. Москва: Советский композитор, 248.

Москаленко, В. (2012). Лекции по музыкальной интерпретации: учеб. пособ. Киев: Клякса, 272.

Томашевский, М. \& Акопян, Л. (Ред.) (2011). Шопен. Человек, творчество, резонанс. (Пер. с польск. Л. Акопяна, Е. Янус). Москва: Музыка, 840.

Фишер, Э. (1977). Музыкальные наблюдения. Исполнительское искусство зарубежных стран, 8, 199-228. Москва: Музыка.

Шопен, Ф. (1989). Письма (Tm. 1-2). Т. 1. Москва: Музыка, 487.

Taruskin, R. (2008). History of the Western music (Vol. 1-5). Vol. 3. Music of the nineteenth century. Oxford University Press, 923. 


\section{REFERENCES}

Bendas, T. V. (2006) Gendernaya psikhologiya [Gender Psychology]. (Textbook). St. Petersburg: Piter [in Russian].

Chopin, F. (1989). Pisma [Letters]. (Vols. 1-2). (Vol. 1). Moscow: Muzyka [in Russian].

Fisher, E. (1977). Muzykalnye nablyudeniya [Musical observations]. Ispolnitelskoe iskusstvo zarubezhnykh stran - Performing art of foreign countries, 8, 199228. Moscow: Muzyka [in Russian].

Gapova, E., \& Usmanova, A. (Comp.) (2000). Antologiya gendernoy teorii [Anthology of gender theory]. Minsk: Propilei [in Russian].

Gigolaeva-Yurchenko, V. (2012). Genderno-ispolnitelskiy analiz romansov S. Rakhmaninova: «O net, molyu, ne ukhodi» (I. Arkhipova) i «Polyubila ya na pechal svoyu» (B. Khristov) [Gender performing analysis of S. Rachmaninoff's romances: "Oh no, please, don't leave" (I. Arkhipova) and "I fell in love with my sorrow" (B. Khristov)]. Problemy vzaiemodii mystetstva, pedahohiky ta teorii i praktyky osvity - Problems of interaction of art, pedagogy and theory and practice of education, 34, 293-301 [in Ukrainian].

Korykhalova, N. (1979). Interpretatsiya muzyki [Interpretation of music]. Leningrad: Muzyka [in Russian].

Mazel, L. A. (1971). Issledovaniya o Shopene [Researches about Chopin]. Moscow: Sovetskiy kompozitor [in Russian].

Moskalenko, V. (2012). Lektsii po muzykalnoy interpretatsii [Lectures on musical interpretation]. Kiev: Klyaksa [in Russian].

Taruskin, R. (2008). History of the Western music (Vol. 1-5). Vol. 3. Music of the nineteenth century. Oxford University Press, 923.

Tomashevskiy, M. \& Akopyan, L. (Eds.) (2011). Shopen. Chelovek, tvorchestvo, rezonans [Chopin. Man, creativity, resonance] (Transl. from Polish by L. Akopyan, E. Yanus). Moscow: Muzyka [in Russian].

Стаття надійшла до редакиї 15.11.2019 р. 